\title{
NF-Kappa-B Inhibitor Alpha
}

National Cancer Institute

\section{Source}

National Cancer Institute. NF-Kappa-B Inhibitor Alpha. NCI Thesaurus. Code C17678.

NF-kappa-B inhibitor alpha (317 aa, $236 \mathrm{kDa}$ ) is encoded by the human NFKBIA gene.

This protein is involved in the cytoplasmic localization of the nuclear factor kappa B

(NFkB) complex, which inhibits NFkB-mediated gene expression. 